\title{
A simulation Model for Predicting the Performance of PV Powered Space Heating System in Egypt
}

\author{
F. H. Fahmy1, A. A. Nafeh, N. M. Ahamed and H. M. Farghally \\ 1Electronics Research Institute, \\ National Research Center Building, Cairo, Egypt
}

\begin{abstract}
Due to the increasing demand for clean, accessible, unexhausted and more economical energy sources, the utilization of solar energy is gaining worldwide momentum. In this work, two main renewable energy resources are considered, the solar energy and biomass energy. The mathematical model and simulation of the global space heating system components (the thermal and the electrical subsystems) are developed.

The PI controller is developed to provide the space heating system with the suitable actions, which directly adjust the water flow rate through the space heating equipment (i.e. hot water radiator) using thermostatic valves to fix the indoor temperature at $25{ }^{\circ} \mathrm{C}$

It is observed that the overall power management strategy is effective and the power flows among the PV arrays, batteries and the load demand is balanced successfully in the electrical subsystem .While in the thermal subsystem, the results show that the designed control techniques enables the space heating system to be in correct operation during night hours d cloudy days.
\end{abstract}

\section{Keywords:}

photovoltaic generator, battery, solar collector, radiator,

\section{Introduction}

Renewable energy resources such as biomass, solar and wind are abundant energy sources in Egypt remote areas [1, 2]. Using renewable energy poses very little environment risk. Solar energy utilization is generally divided into two categories, i.e., electric energy production and thermal energy production. Solar energy is often used to directly heat a house or building. during winter seasons. It is accomplished by the use of special equipments called radiators. Besides being used for heating, solar energy can be directly converted to electricity using photovoltaic cells.

This work develops the mathematical models for the proposed global space heating system. The heating system consists of two subsystems, the electrical and the thermal one. The electrical system contains the photovoltaic generator and the battery which are designed to supply the different electrical loads of system. The thermal system comprises the solar collector, the storage tank, the biogas heater and the radiator.

the heating process is accomplished in a remote site of Sante Catherine, which is far from the national grid of Egypt.

\section{The Proposed Space Heating System Components}

The block diagram of the hot water and space heating system is shown in Fig. 1. The diagram consists of two subsystems which are the electrical subsystem and the solar thermal subsystem which are introduced as follows.

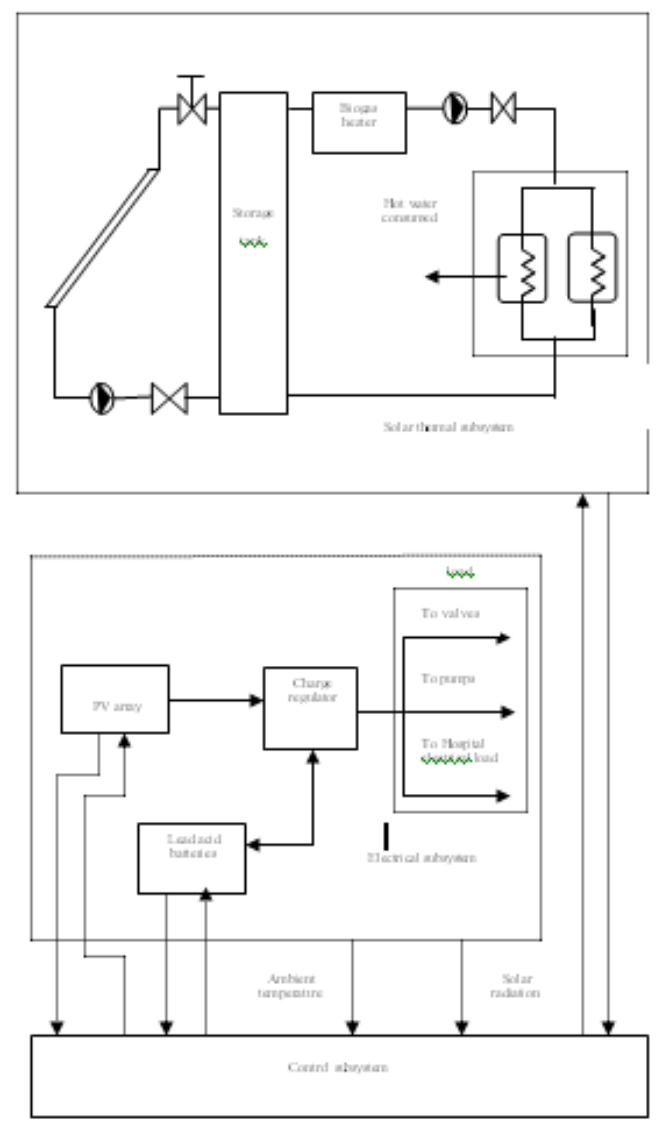

Fig. 1 The proposed heating system.

A. The electrical subsystem

This subsystem is the source of the electrical energy required to supply DC power to the system's electrical loads. Therefore, the PV array and battery subsystem must be sized to 
provide continuous DC power to valves, pumps and building electrical load.

\section{B. The thermal subsystem}

This subsystem is responsible for providing the building with the amount of heat which is suitable for the heating process. The solar thermal system consists mainly, of four components as shown in Fig.1, these component are the solar collector, the storage tank, the biogas heater, and the radiator. The main function of the solar collector is directly utilize the energy from the sun to heat the water that passes through it [3]. Also, the solar collector is considered as the main source of heat energy in the thermal system. The output water from the collector, which is heated to a specified temperature, is stored in a storage water tank. This tank is used to maintain the gained heat energy of the water till the time of utilization. If the temperature of the outlet water from the tank is lower than a certain value, then an auxiliary heater (i.e., bio-gas one) will be utilized to raise the temperature of the water to the desired value

\section{The Electrical Subsystem Mathematical Modeling}

\section{A. The pv array modeling}

The equations describing the operation of a PV array are written as [4,5]

$$
I_{P V}=n_{p} I_{L G}-n_{p} I_{o s}\left(\exp \left(\mathrm{gV} / \mathrm{n}_{\mathrm{s}}\right)-1\right)
$$

Where

$$
\begin{aligned}
& \left.\mathrm{I}_{\mathrm{os}}=\mathrm{I}_{\mathrm{or}}\left[\frac{\mathrm{T}}{\mathrm{T}_{\mathrm{r}}}\right]^{3} \exp \frac{\mathrm{qE}_{\mathrm{GO}}}{\mathrm{BK}}\left(\frac{1}{\mathrm{~T}_{\mathrm{r}}}-\frac{1}{\mathrm{~T}}\right)\right) \\
& g=q / A K T \\
& I_{L G}=\left[I_{s c}+K_{1}\left(T_{c}-28\right)\right] * \frac{G}{1000}
\end{aligned}
$$

While, the array temperature $T_{c}$ is given, approximately, by the relation [ 6 ]

$$
T_{c}=T_{a i r}+0.3 * G \%
$$

where

$\mathrm{I}_{\mathrm{PV}} \quad$ PV array output current, A.

$\mathrm{V}_{\mathrm{PV}}$ array output voltage, $\mathrm{V}$.

$\mathrm{n}_{\mathrm{s}} \quad$ Number of cells connected in series.

$\mathrm{n}_{\mathrm{p}} \quad$ Number of parallel strings.

$\mathrm{I}_{\mathrm{LG}} \quad$ Light generated current, A.

$\mathrm{I}_{\text {or }} \quad$ Reverse saturation current at $\mathrm{T}_{\mathrm{r}}$ ( 19.97 $\left.\times 10^{-6} \mathrm{~A}\right)$.

$\mathrm{A}=\mathrm{B}$ Ideality factors (1.92).

K Boltzmann's constant $\left(1.38 \times 10^{-23}\right.$ joule / K).

Q Electronic charge

(1.602 $\times 10^{-19}$ coulomb).

$\mathrm{T}_{\mathrm{r}} \quad$ Reference temperature (301 K).

$\mathrm{I}_{\mathrm{os}} \quad$ Reverse saturation current at operating temperature, $\mathrm{A}$.

Tc Cell temperature, ${ }^{\circ} \mathrm{C}$.

$\mathrm{T}$ Cell temperature, $\mathrm{K}$.

$K_{1} \quad$ Short-circuit current temperature

coefficient $\left(0.00017 \mathrm{~A} /{ }^{\circ} \mathrm{C}\right)$.

$G \quad$ Cell illumination, $\mathrm{W} / \mathrm{m}^{2}$.

$\mathrm{I}_{\mathrm{sc}} \quad$ Cell short-circuit current at $28{ }^{\circ} \mathrm{C}$ and $1000 \mathrm{~W} / \mathrm{m}^{2}$ (2.52 A).

$\mathrm{E}_{\mathrm{Go}} \quad$ Band gap for silicon (1.11 ev).

\section{B. The lead acid battery modeling}

The battery has two modes, the first one is during the night and shadowing case at which the battery feeds the load which called discharge. The second one occurs when the PV arrays has generated enough power to feed the load and charge the battery. The battery model in the two modes will be mentioned below.

\section{a. Charge voltage modeling}

During charge period, the current voltage relationship is given by [29]:

$v_{B C}=v_{r}+\frac{I_{B}}{B C}\left[R_{i}+\frac{0.189}{(1.142-S O C)}\right]+(S O C-0.9) \ln \left(300 \frac{I_{B}}{B C}+1\right)(6)$

The last term is included only if the first two terms summition is more than $2.29 \mathrm{~V}$ [6].

b. Discharge voltage modeling 
The current and voltage during discharge can be discribed in terms of the state of charge (SOC) of the cell. The battery state of charge is the instantaneous ratio of the actual amount of charge stored in the battery and the total charge capacity of the battery at a certain battery current (ranging from 0.3 to 1.0) which is represented in Eq. 7.

$$
\begin{aligned}
& v_{B D}=v_{r}-\frac{I_{B}}{B C}\left(\frac{0.189}{S O C}+R_{i}\right) \\
& v_{r}=2.04\left[1-0.001\left(T_{c}-T_{r}\right)\right] \\
& R_{i}=0.15\left[1-0.02\left(T_{c}-T_{\mathrm{r}}\right)\right]
\end{aligned}
$$

In the model, it is represented in Eq. (10) $[7,8,9]$

$$
\begin{aligned}
& S O C=S O C_{o}+\frac{Q}{B C} \\
& Q=\int_{0}^{t} I_{B} d t
\end{aligned}
$$

Where

$R_{i} \quad$ The internal resistance of the battery cell.

$\mathrm{V}_{\mathrm{r}} \quad$ The rest voltage of the battery.

$\mathrm{SOC}_{\mathrm{O}}$ The previous state of charge.

SOC The state of charge.

BC Battery capacity.

Q The amount of exchanged charge.

$\mathrm{I}_{\mathrm{B}} \quad$ Battery current.

$\mathrm{V}_{\mathrm{B}} \quad$ Battery voltage during charge case.

$\mathrm{V}_{\mathrm{BD}}$ Battery voltage during discharge case.

\section{The Thermal System Mathematical Modeling}

This model describes the performance of the complete components of the thermal system such as the solar collector, the storage tank, the bio gas heater and the hot water radiator.

\section{A. Modelling of the solar collector}

A flat plate solar collector type will be used to absorb the solar energy and transfers it into the water that flows inside its parallel tubes, which are attached to a black metal plate. This type of collectors absorb both the beam and diffuse components of the solar radiation. Therefore, it still work when the beam component is cut off by the effect of clouds. The water in the collector will absorb the sun's energy with the rate;

$$
\dot{Q}_{a b s}=(\tau \alpha)_{e f f} A_{c} G
$$

and will loss a certain amount of heat energy to the environment, $\dot{Q}_{a m b}$, given by:

$\dot{Q}_{\text {amb }}=\bar{U}_{c} A_{c}\left(T_{\text {cout }}-T_{\text {air }}\right)$

Where

$\tau$ Transmissivity of the collector (fraction of incident energy transmitted).

$\alpha \quad$ Absorbitivity of the collector (fraction of insolation).

$(\tau \alpha)$ eff Effective absorbance - transmissivity of collector's cover (0.8).
$A_{c} \quad$ Collector's area $\left(2 \mathrm{~m}^{2}\right)$.
$\mathrm{G}$ Solar illumination $\left(\mathrm{W} / \mathrm{m}^{2}\right)$.

$\bar{U}_{c} \quad$ Overall thermal loss coefficient $(8.38 \mathrm{~W} /$ $\left.\mathrm{m}^{2} \mathrm{~K}\right)$.

$\mathrm{T}_{\text {cout }}$ Water temperature at the collector outlet $(\mathrm{K})$.

$\mathrm{T}_{\text {air }} \quad$ Ambient temperature(K).

The energy balance of the collector will lead to the following differential equation $[11,12]$ :

$$
\frac{d T_{\text {cout }}}{d t}=-\frac{\dot{m}_{c w}}{\rho_{w} V_{c w}}\left(T_{c o u t}-T_{c i n}\right)+\frac{\dot{Q}_{a b s}-\dot{Q}_{a m b}}{\rho_{w} V_{c w} C_{p w}}
$$

where

$\mathrm{T}_{\text {cin }} \quad$ water temperature at the collector inlet.

$m_{c w}$ mass flow rate of water in the collector.

$\mathrm{C}_{\mathrm{pw}}$ specific heat of water.

$\rho_{w} \quad$ density of water.

$\mathrm{V}_{\mathrm{cw}} \quad$ volume of water in the collector.

\section{B. Modelling of the storage tank}

The used tank is considered to be composed of ten identical layers due to the stratified nature of the storage water tanks Therefore, an energy balance on a general layer (m) of the tank yields to the following equation $[11,12]$ : 


$$
\begin{aligned}
& \frac{d T_{m}}{d t}=\frac{\dot{Q}_{c m}}{m_{m} C_{p w}}+\frac{\dot{Q}_{\text {Lm }}}{m_{m} C_{p w}}-\frac{\dot{Q}_{\text {Loss }}}{m_{m} C_{p w}} \\
& \dot{Q}_{c m}= \begin{cases}\dot{m}_{c w} C_{p w}\left(T_{m-1}-T_{m}\right) & , T_{\text {cout }}>T_{1} \\
\dot{m}_{c w} C_{p w}\left(T_{\text {cout }}-T_{m}\right) & , T_{m-1}>T_{\text {cout }}>T_{m}\end{cases} \\
& \dot{Q}_{\text {Lm }}= \begin{cases}\dot{m}_{\text {Lw }} C_{p w}\left(T_{m+1}-T_{m}\right) & , T_{\text {Lout }}<T_{10} \\
m_{\text {Lw }} C_{p w}\left(T_{\text {Lout }}-T_{m}\right) & , T_{m+1}<T_{\text {Lout }}<T_{m}\end{cases} \\
& \dot{Q}_{\text {Loss }}=\bar{U}_{s t} A_{m}\left(T_{m}-T_{\text {air }}\right)
\end{aligned}
$$

Where

Tm Temperature of layer $\mathrm{m}(\mathrm{m}=1,2,3, \ldots$, 10).

$\mathrm{T}_{\text {Lout }}$ Outlet temperature of water from the load side.

$\mathrm{m}_{\mathrm{m}} \quad$ Mass of water in layer $\mathrm{m}$.

$m_{L w}$ Mass flow rate of water in the load side.

$\mathrm{A}_{\mathrm{m}} \quad$ Surface area of layer $\mathrm{m}$.

$\bar{U}_{s t} \quad$ Overall loss coefficient for the exposed storage surface $(10.08 \mathrm{~W} / \mathrm{m} 2 \mathrm{~K})$.

\section{Modeling of the bio-gas heater}

An auxiliary thermal energy $\dot{Q}_{\text {add }}$ will be supplied to the outlet water from the tank when the energy of the water is lower than the required temperature. The energy balance of the bio-gas burner and heater is given by:

$$
\begin{gathered}
\frac{d T_{w h}}{d t}=-\frac{m_{L w}}{\rho_{w} V_{\text {heater }}}\left(T_{w h}-T_{1}\right)+\frac{\dot{Q}_{\text {add }}}{\rho_{w} V_{\text {heater }} C_{p w}} \\
\dot{Q}_{\text {add }}=4.18 \times C V_{\text {bio }} \times \dot{m}_{\text {bio }} \times \eta_{\text {heater }}
\end{gathered}
$$

Where

$\mathrm{T}_{\mathrm{wh}} \quad$ Outlet temperature of water from the bio-gas heater.

$V_{\text {heater }}$ Volume of the heater.

$\mathrm{CV}_{\text {bio }} \quad$ Calorific value of bio-gas.

$m_{\text {bio }} \quad$ Mass flow rate of bio-gas fuel. $\eta_{\text {heater }} \quad$ Heater efficiency.

\section{D) Modeling of the hot water radiator}

The heat load and capacity of hot water radiators could be modeled as follows [12]. The heat load for a building changes linearly with the difference between indoor and outdoor temperatures:

$$
Q=Q_{0} \times\left(T_{\text {in }}-T_{\text {out }}\right) /\left(T_{\text {in }}-T_{\text {out }, 0}\right)
$$

Where

Q The heat load $(\mathrm{kW})$.

$\mathrm{T}_{\mathrm{in}}$ Indoor temperatures $\left({ }^{\circ} \mathrm{C}\right)$.

$\mathrm{T}_{\text {out }}$ Outdoor temperatures $\left({ }^{\circ} \mathrm{C}\right)$.

$\mathrm{Q}_{0} \quad$ The design heat load (KW).

$\mathrm{T}_{\text {out }, 0}$ The design outdoor temperature $\left({ }^{\circ} \mathrm{C}\right)$.

The heat capacity of a hot water radiator depends on the logarithmic mean temperature difference (LMTD, ${ }^{\circ} \mathrm{C}$ ) and is estimated at changing values of LMTD as given in Eq .21. The value of LMTD between the indoor space and the water circulating through the radiator is calculated according to the following equation:

$$
\begin{aligned}
& Q=Q_{0}\left(\Delta T_{i m} / \Delta T_{l m, 0}\right)^{n} \\
& \Delta T_{l m}=\frac{T_{S}-T_{r e}}{\ln \left[\frac{T_{S}-T_{i n}}{T_{r e}-T_{i n}}\right]}
\end{aligned}
$$

The heat transferred from a radiator is also equal the enthalpy change of the water passing through the radiator and the difference between the supply and return temperatures of the circulating water is calculated according to Eq. 24.

$Q=\dot{V} \rho C\left(T_{S}-T_{r e}\right)$

\section{Where}

$\mathrm{T}_{\mathrm{s}} \quad$ The supply temperatures of the water $\left({ }^{\circ} \mathrm{C}\right)$.

$\mathrm{T}_{\mathrm{re}}$ The return-temperatures of the water $\left({ }^{\circ} \mathrm{C}\right)$.

$\Delta \mathrm{T}_{\mathrm{lm}, 0}$ The value of LMTD that is calculated under design conditions.

$\dot{V} \quad$ The flow rate $\left(\mathrm{m}^{3} / \mathrm{s}\right)$. 
$\rho \quad$ The density $\left(\mathrm{kg} / \mathrm{m}^{3}\right)$.

$\mathrm{C}$ The specific heat of the circulation water $\left(\mathrm{Kj} / \mathrm{kg}{ }^{\circ} \mathrm{C}\right)$.

\section{Simulation Results}

The basic goal of this work is to verify that the simulation models would yield a controlled heating system. The performance of the complete components in both the thermal and electrical subsystems together with the corresponding control signals is necessary to evaluate the control capability of the proposed

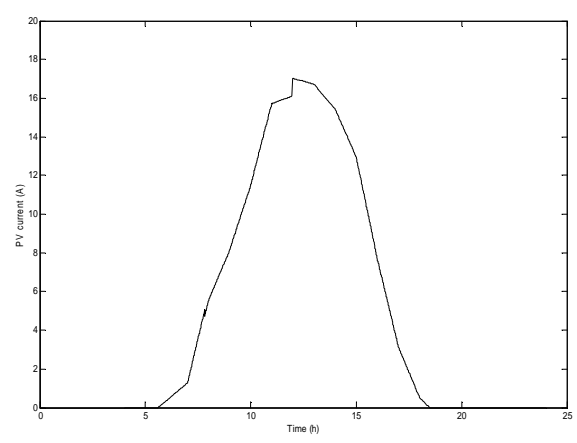

(a) During sunny day

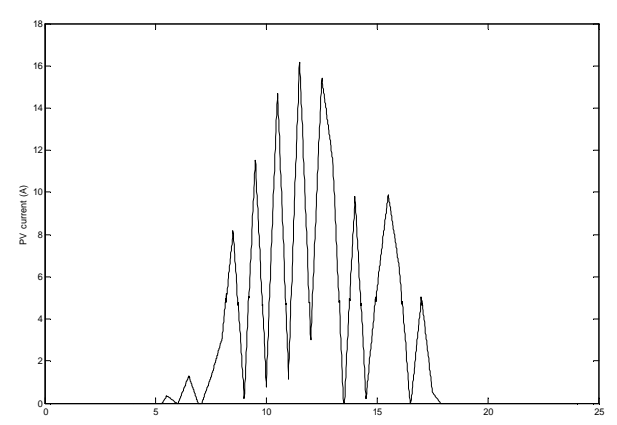

(b) During cloudy day

Fig.2 The PV array current versus time.

\section{b) Battery Performance}

Another important element of a stand-alone PV system is the battery. The battery is necessary in such a system because of the fluctuating nature of the output delivered by the PV arrays. Thus, during the hours of sunshine, the PV system is directly feeding the load, while the excess electrical energy being stored in the battery. During the night, or during a period of low solar irradiation, energy is supplied to the

\section{a) PV Array Performance}

The typical current, voltage and power behaviors of the PV array system in sunny and cloudy days are shown in Figs. 2 to 4 respectively. The plot for the PV current and power (Fig.2 \& Fig. 4) indicates that the variations of PV current and power follow the variations of the irradiation There will be time periods when the PV system is unable to meet the load demand (night hours). This implies that the PV systems will need a storage system that will be able to provide enough energy during w.......... 1 .

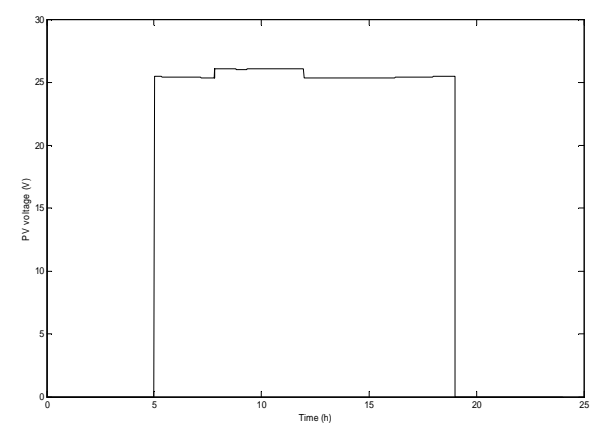

(a) During sunny day

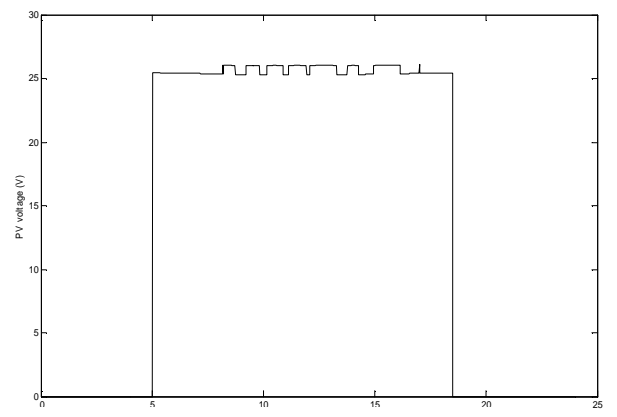

(b) During cloudy day

Fig.3 The PV array voltage versus time

load from the battery. The battery performance is shown in Figs. 5 to 8. The battery current (Fig. 5) increases continuously as long as solar illumination power exceeds load demand, the apparent drop of the current to zero value, is due to the full charge of the battery, any excess power is dissipated through a resistive element. The percentage of rated capacity remaining in the battery is called the battery state of charge. The curve showing the battery fractional SOC 
versus time is indicated in Fig. 7. The battery starts with full capacity at SOC equal $100 \%$, then battery begins discharging up to 8 o'clock, after the period of discharging, battery

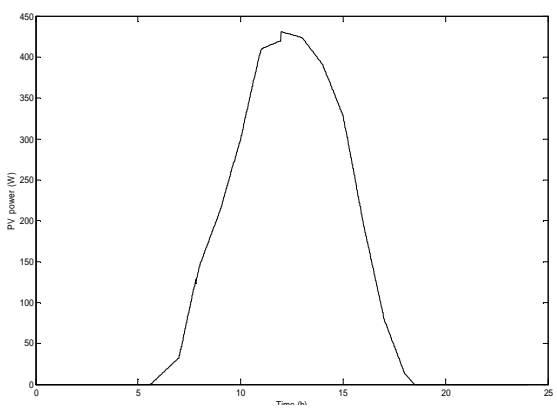

(a) During sunny day

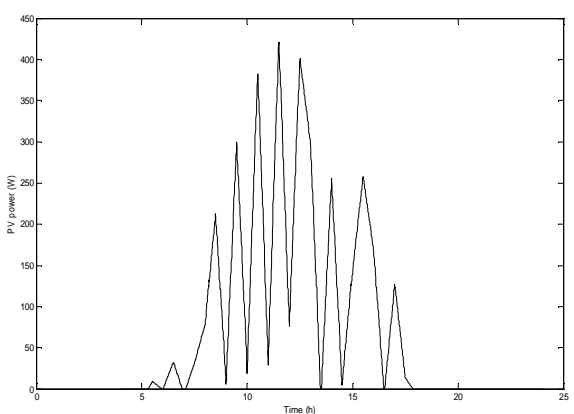

(b) During cloudy day

Fig. 4 The PV array power versus time.

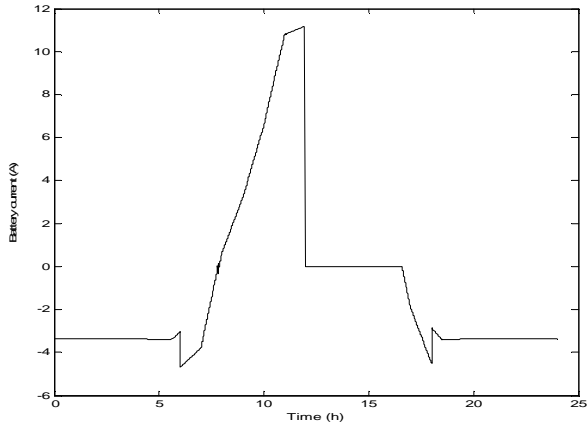

(a) During sunny day

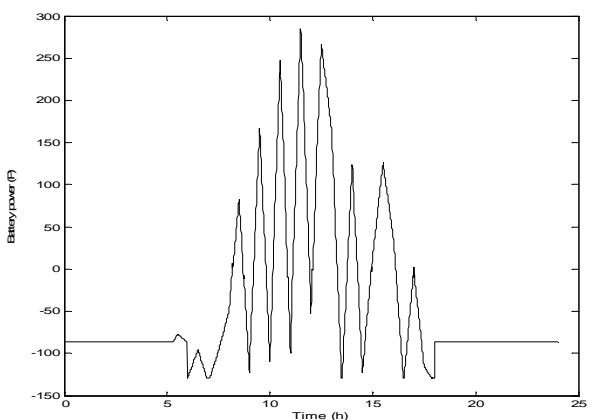

(b) During cloudy day

Fig.5 The battery current versus time. recharge again until reach its full capacity at mid day. And finally it will be discharging again during the night.

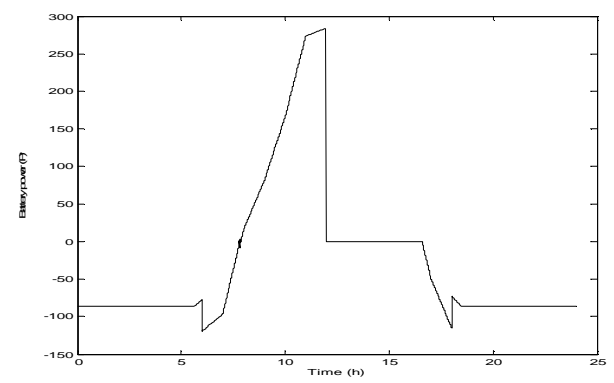

(a) During sunny day

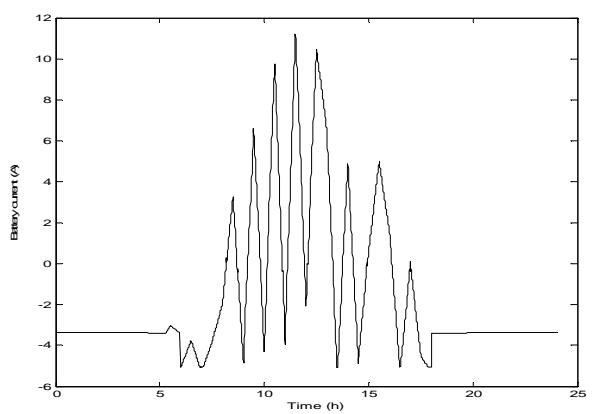

(b) During cloudy day

Fig. 6 The battery power versus time.

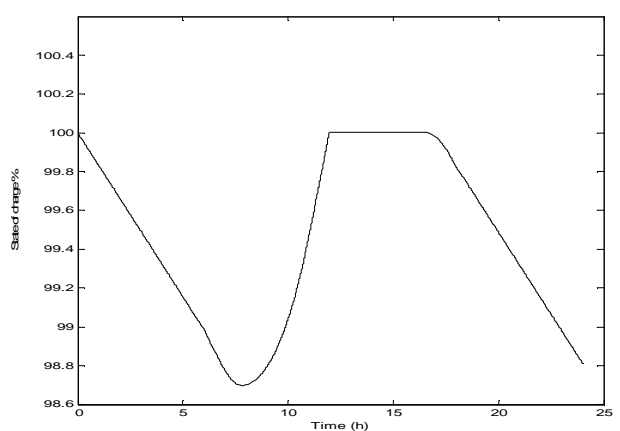

(a) During sunny day

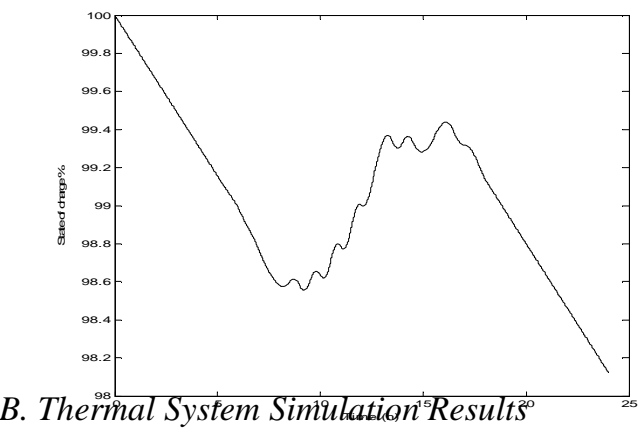

The results $\quad$ (b) During cloudy day

Fig. 7 The lead acid battery state of charge versus time. 
even in case of rapidly changing atmospheric conditions .The purpose of the temperature control system is to adjust the indoor temperature $T_{\text {in }}$ at $25^{\circ} \mathrm{C}$.

\section{a. Solar Water Collector Performance}

The performance of the collector during the sunny and cloudy days is shown in Fig. 8 which indicates the temperature of the water at the inlet and outlet sides of the collector.

It is shown from Fig. 9 that the used collector is able to heat the water that flows through it, whenever there is solar illumination; where the heating of the water is proportional to the incident insolation level.Also, it is cleared that the water continues to flow in the collector as long as the temperature of the water at the collector outlet is greater than that at the collector inlet. The initial apparent-rise of the outlet temperature compared with the inlet one, for the two cases, is due to: using the same value of the initial conditions for the two temperatures, the water does not flow in the collector during the night period, and the corresponding variation in the ambient temperature.

\section{b. Hot water radiator performance}
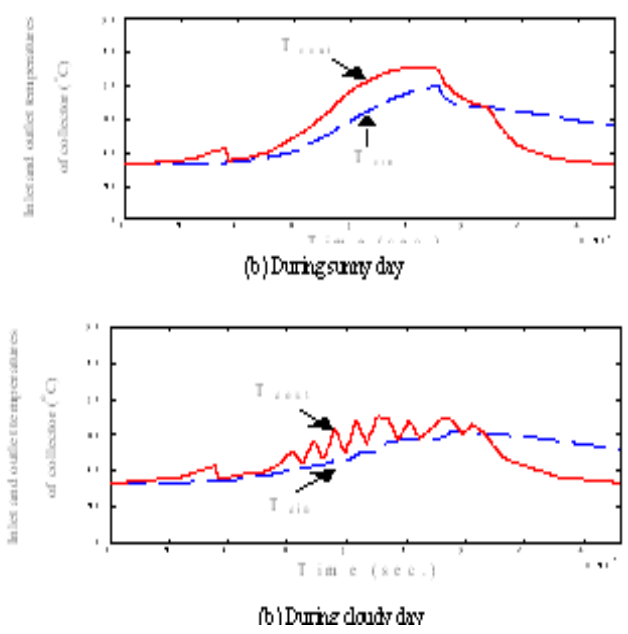

Fig. 8 Inlet and outlet temperatures of the collector.
The PI controller is developed to provide the system with the suitable actions, which directly adjust the water flow rate through the space heating equipment (i.e. hot water radiator) using thermostatic valves to keep constant indoor temperature

Figure 10 includes the output control signal of the PI controller. The control signal of controller varies in inverse proportion to the outdoor temperature (ambient temperature) shown in Fig11

The corresponding water flow rate $m_{w}$ in radiators for the hospital building is shown in Fig. 12. When the outdoor temperature increases, a thermostatic valve decreases the water flow rate, passing through the radiator to

keep indoor temperature at the desired point $\left(25^{\circ} \mathrm{C}\right)$ as shown in Fig. 12. The mass flow rate of the water is directly proportional to the corresponding control signal of the corresponding controller.

It also observed from this figure that the maximum water flow occurs at mid night at minimum ambient temperature, while the minimum flow occurs at noon at maximum ambient temperature.

Figure 12 shows the response of the indoor temperature from the system using the PI controller.
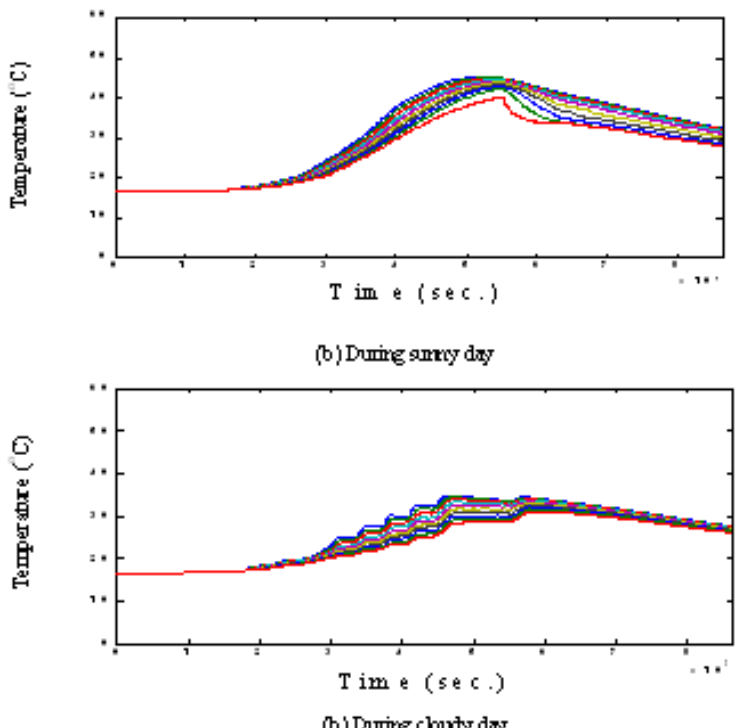

Fig. 9 Temperature of the tank layers 

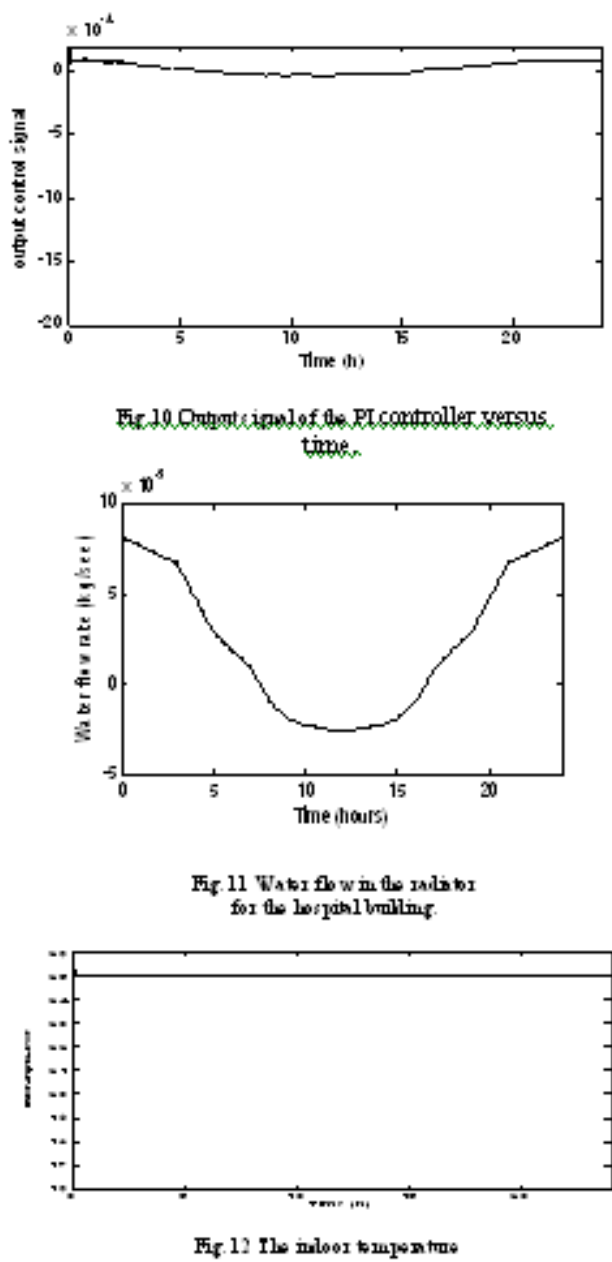

\section{Conclusion}

A complete mathematical modeling for the different components in both the electrical and thermal subsystems is developed. Simulation studies have been carried out to verify the electrical and thermal subsystem performance under different scenarios using an estimated electrical and thermal load profiles and real weather data of the selected remote area. The results show that the overall power management strategy is effective and the power flows among the PV arrays, batteries and the load demand is balanced successfully in the electrical subsystem .While in the thermal subsystem, the results illustrate that the designed control techniques enables the space heating system to be in correct operation and to fix the indoor temperature at $25^{\circ} \mathrm{C}$.
Refrences

[1] D. Mukherjee, and S. chakrabarti, "Fundamentals of Renewable Energy Systems", New Delhi, first edition, 2004.

[2] Felix. Farret, M. Godoysimoes, "Integration of Alternative Sources of Energy", John Wiley \& Sons, New Jersey, 2006.

[3]http://www.solarsever.de/wissen/sonne

nkollektoen-e.html\#wie.

[4] G.P.Sharma and Suresh Prasad, "Drying of garlic Cloves by MicrowaveHot Air Combination", Journal of Food Engeneering, Vol. 50, 2001, pp. 99-105.

[5] France Lasnier and Tony Gan Ang, "Photovoltaic Engineering

Handbook", Bangkok, Thailand, 1990

[6] M. M. H. Bhuiyan, "Sizing of Stand Alone PV Power System at Dhaka", Renewable Energy, under published.

[7] T. Markvart, "PV System Sizing Using Observed Time Series of Solar

Radiation", under published, Solar

Energy, 2005.

[8] http://www.abcsolar.com/pdf/2001-09-

$$
\text { 04_500-01-020.pdf. }
$$

[9] Hamdy H. El-Ghetany, "Effect of Hot Water Consumption on Temperature Distributions in Vertical and Horizontal Solar Waterv Storage Tanks", M.Sc.Thesis, Cairo University, 1992.

[10] K. Ogata, "Modern Control Engineering", Prentice-Hall Inc. , Englewood Cliffs, N. J. , 1990.

[11] Serhan $\mathrm{Ku}^{*} \mathrm{c}_{s} \mathrm{u}^{* \mathrm{ka} a}$, "The thermal effects of some control logics used in GDHS", Applied Thermal Engineering, Vol. 27, pp. 14951500, 2007. 